\title{
Plant pigments and light penetration in intertidal sediments ${ }^{1}$
}

\author{
W. Rowland Taylor and Conrad D. Gebelein \\ Department of Oceanography and the Chesapeake Bay Institute, \\ The Johns Hopkins University, Baltimore, U.S. A., and \\ Marine Biological Laboratory, Woods Hole, U. S. A.
}

\begin{abstract}
KURZFASSUNG: Pflanzliche Pigmente und Lichtpenetration in Sedimenten des Gezeitenbereichs. Die Verteilung pflanzlicher Pigmente und die Lichtpenetration wurden in vier verschiedenen Sedimenttypen untersucht, und zwar bei Barnstable Harbor, Massachusetts, USA. Mit einer Ausnahme erwies sich die Lichtattenuation als Funktion der Partikelgröße des Sediments. Obgleich lokale Unterschiede in der Pigmentverteilung an den einzelnen Untersuchungsstationen beobachtet wurden, war das Verteilungsmuster grundsätzlich ähnlich. Die Kon»entrationsmaxima lagen bei allen Pigmenten im obersten Sedimentmillimeter. Die Konzentrationen der Chlorophylle und des Fucoxanthins verringerten sich allmählich mit zunehmender Tiefe; sie waren jedoch bei $5 \mathrm{~cm}$ Tiefe mit 20 bis $50 \%$ der Oberflächenwerte noch sehr hoch. Dic Konzentrationen von Karotinen und anderen Xanthophyllen verringerten sich nicht mit der Tiefe. Die Verbreitung beweglicher pennater Diatomeen wurde an einer Station geprïf; es reigte sich, daß die Mehrzahl der Individuen auf die obersten $3 \mathrm{~mm}$ beschränkt war. Lcbende Diatomcen wurden bis zu einer Tiefe von $5 \mathrm{~cm}$ gefunden. Der Gchalt an organischer Substanz im Sediment wurde bestimmt und mögliche Korrclationen zwischen dessen prozentualem Pigmentantcil und einigen physikalischen Parametern der Stationen erörtert.
\end{abstract}

\section{INTRODUCTION}

Chlorophyll concentrations are widely used in ecological studies as indices of plant material available in ecosystems. However, the technique seldom has been applied to intertidal benthic studies. An exception is the study of the intertidal fauna of Barnstable Harbor, Massachusetts (U.S. A.), by SANDers et al. (1962). Very high chlorophyll concentrations were found at two of their six stations, but their method did not differentiate between the various photosynthetic pigments and possible degradation products. Since degradation products may have been significant (Patterson \& Parsons 1963), a quantitative study of the major photosynthetic pigments of four sediment types in the Barnstable Harbor was undertaken (TAYlor \& Gebelein 1964). Con-

1 Contribution No. 90 Chesapeake Bay Institute, The Johns Hopkins University. Partially supported by the U. S. Atomic Energy Commission (Contract AT [30-1] 1477), and the Office of Naval Research (Contract Nonr 248 [54]) and NIH training grant 5 T1 GM 535 04. 
current with these analyses, data on light penetration through these sediments was collected.

The hydrography of Barnstable Harbor has been described by Ayers (1959). The tidal range in the harbor is approximately 3.5 meters. All of the sampling stations used in this study are exposed for several hours at low tides. Station $\mathrm{A}$ is located on the south shore of the harbor, approximately 100 meters east of location 14 on AYERs' Figure 1. The area is not subjected to strong tidal currents and the sediment has a high silt content. The invertebrate fauna has not been thoroughly studied at Station A but the predominant organism is Amphitrite ornata. Station $\mathrm{M}$ was a protected tidal flat consisting of soft flocculent mud and is approximately 0.75 kilometers west of Station A. Large populations of polychaetes are found in these sediments but neither quantitative nor qualitative studies of the invertebrate fauna have been made. Station $S$ is a sand flat subject to relatively strong tidal currents. It corresponds to SANDERs' Station $\mathrm{D}$ and is located approximately at position 4 on Ayers' Figure 1. On the basis of biomass it is predominated by the annelids Streblosio benedici, Clymenella torquata and the snail Polynices duplicata (SANDers et al. 1962). Station D is also a sand flat but tidal currents are not as strong as at Station $S$. In the summertime, the sediments at Station $D$ are characterized by large patches of migratory diatoms appearing on the surface at low tide (TAYLOR 1964). Its approximate location is position 12 on Ayers' Figure 1 and corresponds roughly to SANDERS' Station F. The predominate invertebrates are Glycera dibranchiata, Clymenella torquata and Gemma gemma (SANDERs et al. 1962).

\section{METHODS}

Samples were collected at the stations during the summer of 1964 on four occasions when low tide and solar noon closely coincided. Two cores, $3.5 \mathrm{~cm}$ in diameter, were collected, one for pigment analysis and the other for determination of organic content of the sediment. The cores were carefully sectioned in the field, separating the top $1 \mathrm{~mm}$ and five $1 \mathrm{~cm}$ sections.

The pigment analyses were made as soon as the samples were returned to the laboratory. Each sediment sample was extracted three times with $20 \mathrm{ml}$ of methanol. The extracts were concentrated and subjected to paper chromatography by the method of JEFFREY (1961). The resulting pigment spots were cut from the paper and eluted by the solvents indicated below, and their concentrations were determined by measuring optical density with a Beckman DU spectrophotometer at the wave lengths indicated: chlorophyll-a, ether, $657 \mathrm{~m} \mu$; chlorophyll-c, propanol, $440 \mathrm{~m} \mu$; diatoxanthin and diadinoxanthin, ether, $472 \mathrm{~m} k$; fucoxanthin and neofucoxanthin, ether, $470 \mathrm{~m} \mu$; carotene, ether, $470 \mathrm{~m} \mu$; phaeophytin-a, ether, $657 \mathrm{~m} \mu$. The extinction coefficient values used were those given by KAR (1937), Karrer \& WURGLer (1943), SMtTH \& BeniteZ (1955), and ZscherLe \& Comar (1941).

The organic content was determined by the loss of weight on ashing unwashed sediments at $400{ }^{\circ} \mathrm{C}$ in a muffle furnace. Particle size distribution in the sediments was determined by wet sieving through standard screens. The penetration of solar radiation 
through the upper few millimeters of sediment was measured by the method previously described by TAYLOR (1964).

Cores for the cell counts at Station D were taken in the same manner and at the same time as one of those for pigment analyses. The cores were sectioned in the field and immediately returned to the laboratory. Five $\mathrm{ml}$ of membrane filtered sea water was added to each sediment sample and, after violent shaking with a vortex stirrer, most of the sediment particles were removed by pouring the suspension through coarse bolting cloth. For each sample 10 aliquots were examined on a hemocy tometer slide. Only active motile cells were counted.

Table 1

Pigment concentrations of intertidal sediments in Barnstable Harbor, Massachusetts, U. S. A.; $\mathrm{mg}$ pigment under $\mathrm{m}^{2}$ between depth intervals. Each value is average of four determinations; standard deviation values are given. Line indicates missing data; zero means no pigment detected

\begin{tabular}{|c|c|c|c|c|c|c|}
\hline Pigment & $\begin{array}{l}\text { Depth } \\
\text { Interval }\end{array}$ & $\mathrm{A}$ & $\mathrm{M}^{\mathrm{Sta}}$ & ion & $S$ & $\mathrm{D}$ \\
\hline Chlorophyll-a & $\begin{array}{l}1 \mathrm{~mm} \\
1.1 \mathrm{~cm} \\
2.1 \mathrm{~cm} \\
3.1 \mathrm{~cm} \\
4.1 \mathrm{~cm} \\
5.1 \mathrm{~cm}\end{array}$ & $\begin{array}{l}525.0 \pm 17.0 \\
285.7 \pm 13.0 \\
115.3 \pm 7.8 \\
140.3 \pm 7.8 \\
117.5 \pm 3.2 \\
159.6 \pm 2.2\end{array}$ & $\begin{array}{l}442.8 \pm 30.3 \\
327.8 \pm 22.3 \\
267.5 \pm 13.9 \\
222.1 \pm 6.5 \\
195.3 \pm 8.5 \\
102.8 \pm 2.5\end{array}$ & $\begin{array}{l}224.2= \\
507.1= \\
457.1 \\
285.7 \\
258.9 \\
232.5\end{array}$ & $\begin{array}{l} \pm \quad 4.4 \\
\pm 44.0 \\
\pm 28.5 \\
\pm \quad 4.8 \\
\pm \quad 4.3 \\
\pm \quad 3.6\end{array}$ & $\begin{array}{l}285.2 \pm 10.0 \\
435.7 \pm 37.4 \\
209.6 \pm 8.0 \\
185.3 \pm 8.9 \\
147.8 \pm 6.4 \\
150.3 \pm 5.0\end{array}$ \\
\hline Chlorophyll-c & $\begin{array}{l}1 \mathrm{~mm} \\
1.1 \mathrm{~cm} \\
2.1 \mathrm{~cm} \\
3.1 \mathrm{~cm} \\
4.1 \mathrm{~cm} \\
5.1 \mathrm{~cm}\end{array}$ & $\begin{array}{r}105.0 \pm 4.5 \\
76.2 \pm 2.5 \\
18.0 \pm 0.6 \\
33.9 \pm 2.1 \\
19.5 \pm 0.6 \\
16.5 \pm 1.5\end{array}$ & $\begin{array}{r}128.7 \pm 14.3 \\
54.6 \pm 4.3 \\
119.4 \pm 12.1 \\
55.2 \pm 2.9 \\
48.6 \pm 3.7 \\
27.0 \pm 1.5\end{array}$ & $\begin{array}{r}- \\
90.9 \\
109.2= \\
62.4= \\
58.2= \\
61.2\end{array}$ & $\begin{array}{r} \\
\pm \quad 3.0 \\
\pm 19.5 \\
\pm \quad 2.5 \\
\pm \quad 6.5 \\
\pm \quad 9.5\end{array}$ & $\begin{array}{l}44.1 \pm 3.0 \\
54.9 \pm 3.7 \\
29.4 \pm 1.5 \\
32.1 \pm 1.8 \\
23.4 \pm 0.9 \\
26.4 \pm 1.5\end{array}$ \\
\hline $\begin{array}{l}\text { Diatoxanthin and } \\
\text { Diadinoxanthin }\end{array}$ & $\begin{array}{l}1 \mathrm{~mm} \\
1.1 \mathrm{~cm} \\
2.1 \mathrm{~cm} \\
3.1 \mathrm{~cm} \\
4.1 \mathrm{~cm} \\
5.1 \mathrm{~cm}\end{array}$ & $\begin{array}{l}65.1 \pm 3.8 \\
63.1 \pm 3.0 \\
36.5 \pm 1.8 \\
53.5 \pm 0.9 \\
43.1 \pm 2.8 \\
47.0 \pm 1.8\end{array}$ & $\begin{array}{l}96.5 \pm 7.4 \\
65.8 \pm 2.7 \\
44.3 \pm 2.4 \\
49.5 \pm 2.6 \\
39.5 \pm 1.4 \\
45.5 \pm 2.8\end{array}$ & $\begin{array}{l}-6 \\
65.0= \\
77.6= \\
63.0= \\
66.6= \\
81.6=\end{array}$ & $\begin{aligned} &- \\
&+\quad 4.3 \\
& \pm 1.2 \\
& \pm 1.0 \\
& \pm \quad 1.3 \\
& \pm 2.5\end{aligned}$ & $\begin{array}{l}38.5 \pm 1.0 \\
30.5 \pm 1.4 \\
28.8 \pm 2.1 \\
36.1 \pm 1.8 \\
35.3 \pm 1.4 \\
29.1 \pm 1.5\end{array}$ \\
\hline $\begin{array}{l}\text { Fucoxanthin and } \\
\text { Neofucoxanthin }\end{array}$ & $\begin{array}{l}1 \mathrm{~mm} \\
1.1 \mathrm{~cm} \\
2.1 \mathrm{~cm} \\
3.1 \mathrm{~cm} \\
4.1 \mathrm{~cm} \\
5.1 \mathrm{~cm}\end{array}$ & $\begin{array}{l}82.3 \pm 5.4 \\
70.7 \pm 4.2 \\
26.9 \pm 2.7 \\
20.3 \pm 1.5 \\
34.8 \pm 2.7 \\
34.5 \pm 4.1\end{array}$ & $\begin{array}{r}122.0 \pm 12.2 \\
71.3 \pm 9.1 \\
122.0 \pm 15.2 \\
75.6 \pm 4.5 \\
55.4 \pm 5.1 \\
32.9 \pm 6.0\end{array}$ & $\begin{array}{l}30.2= \\
89.0 \\
85.4 \\
53.4= \\
48.8= \\
42.7\end{array}$ & $\begin{array}{ll} \pm & 4.7 \\
\pm & 6.7 \\
\pm & 6.7 \\
\pm & 4.8 \\
\pm & 3.6 \\
\pm & 2.7\end{array}$ & $\begin{array}{l}51.7 \pm \quad 8.5 \\
86.6 \pm 9.7 \\
40.7 \pm 6.4 \\
29.7 \pm 1.6 \\
28.8 \pm 3.2 \\
30.8 \pm 4.1\end{array}$ \\
\hline Carotene & $\begin{array}{l}1 \mathrm{~mm} \\
1.1 \mathrm{~cm} \\
2.1 \mathrm{~cm} \\
3.1 \mathrm{~cm} \\
4.1 \mathrm{~cm} \\
5.1 \mathrm{~cm}\end{array}$ & $\begin{array}{l}37.8 \pm 1.7 \\
42.6 \pm 0.9 \\
40.0 \pm 1.8 \\
49.6 \pm 1.3 \\
49.3 \pm 2.1 \\
72.8 \pm 3.1\end{array}$ & $\begin{array}{l}47.6 \pm 1.1 \\
36.0 \pm 1.2 \\
32.8 \pm 3.1 \\
41.6 \pm 1.4 \\
38.8 \pm 1.5 \\
45.0 \pm 1.6\end{array}$ & $\begin{array}{l}28.6= \\
76.0= \\
34.6= \\
41.3= \\
48.1= \\
53.5\end{array}$ & 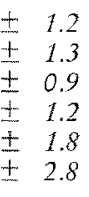 & $\begin{array}{l}25.1 \pm 1.9 \\
31.8 \pm 1.9 \\
52.3 \pm 1.5 \\
38.5 \pm 1.1 \\
37.1 \pm 0.8 \\
32.0 \pm 2.5\end{array}$ \\
\hline Phacophytin-a & $\begin{array}{l}1 \mathrm{~mm} \\
1.1 \mathrm{~cm} \\
2.1 \mathrm{~cm} \\
3.1 \mathrm{~cm} \\
4.1 \mathrm{~cm} \\
5.1 \mathrm{~cm}\end{array}$ & $\begin{aligned} & 0 \\
& 12.1 \pm 0.3 \\
& 13.9 \pm 1.7 \\
& 5.3 \pm 0 \\
& 15.7 \pm 2.5 \\
& 12.5 \pm 1.8\end{aligned}$ & $\begin{array}{l}0 \\
0 \\
0 \\
0 \\
0 \\
0\end{array}$ & & $\begin{array}{l}0 \\
0 \\
0 \\
0 \\
0 \\
0\end{array}$ & $\begin{array}{c}0 \\
0 \\
0 \\
0 \\
11.7 \pm 4.4 \\
22.5 \pm 7.8\end{array}$ \\
\hline
\end{tabular}




\section{RESULTS}

The results of the pigment analyses at the four stations are presented in Table 1. As is seen by the standard deviation values, there was good agreement between the four sets of analyses. Chlorophyll and fucoxanthin concentrations were highest in the

Table 2

Organic content of intertidal sediments in Barnstable Harbor. Per cent dry weight. Each value is average of four determinations

\begin{tabular}{|c|c|c|c|c|}
\hline $\begin{array}{l}\text { Depth } \\
\text { Interval }\end{array}$ & A & $\mathrm{M}$ & $\mathrm{S}$ & $\mathrm{D}$ \\
\hline $1 \mathrm{~mm}$ & 1.95 & 3.75 & 1.01 & 2.01 \\
\hline $1.1 \mathrm{~cm}$ & 0.96 & 1.67 & 1.55 & 0.64 \\
\hline $2.1 \mathrm{~cm}$ & 0.96 & 1.30 & 0.65 & 0.59 \\
\hline $3.1 \mathrm{~cm}$ & 1.03 & 0.93 & 0.49 & 0.83 \\
\hline $4.1 \mathrm{~cm}$ & 0.76 & 0.91 & 0.41 & 0.50 \\
\hline $5.1 \mathrm{~cm}$ & 0.30 & 1.03 & 0.44 & 0.43 \\
\hline
\end{tabular}



Fig. 1: Particle size distribution of intertidal sediments at three stations, Barnstable Harbor, Massachusetts, U. S. A.

surface layer at Stations $A$ and $M$ and just below the surface layer at the two sand flat stations though the fucoxanthin showed a second maximum at $2.1 \mathrm{~cm}$ at Station M. Chlorophyll-a, chlorophyll-c and fucoxanthin concentrations showed a general de- 
crease with depth below the surface or near surface maximum. The remaining xanthophyll concentrations remained relatively constant with depth. Carotenes tended to increase slightly with depth. Phaeophytin-a was found only at Station A and in the deeper parts of the core at Station D.

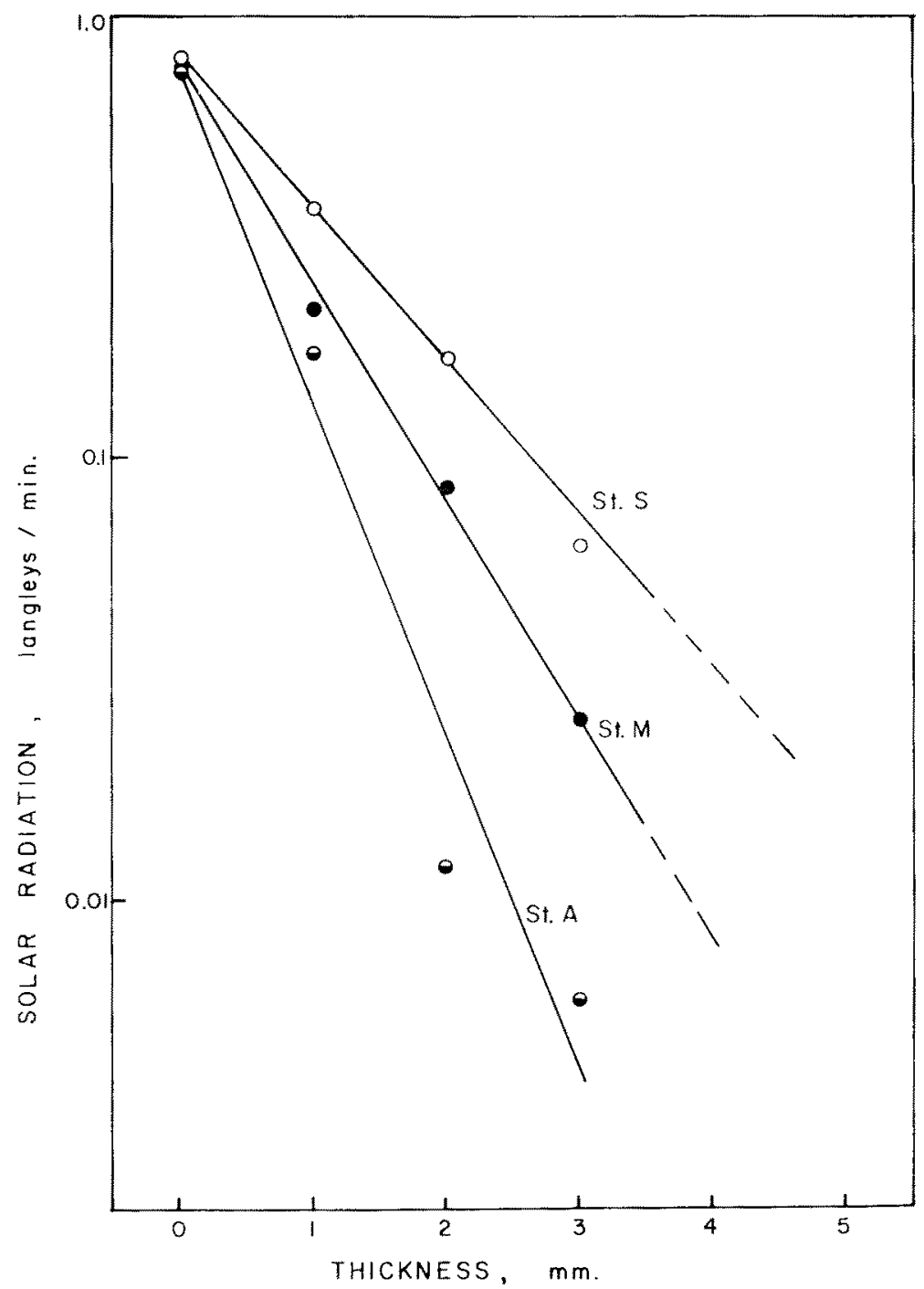

Fig. 2: Penetration of solar radiation through intertidal sediments at three stations, Barnstable Harbor

The organic content of the sediments is given in Table 2. As would be expected the highest organic content was found in the surface layer. The particle size distribution of these sediments is presented in Figure 1. Station $S$, with the strongest tidal 
currents, has the largest mean particle size. Particle size data for Station D has been previously reported (TAYLOR 1964). It is a well-sorted sand with almost all of the particles between 63 and 177 microns in diameter.

The penetration of solar radiation through the upper few millimeters of the sediments at Stations A, M and $S$ is given in Figure 2. Similar data for Station D has been reported by TAYLOR (1964). These data are summarized as attenuation coefficients in Table 3.

Table 3

Attenuation coefficients of upper few millimeters of sediments in Barnstable Harbor

\begin{tabular}{|cc|}
\hline Station & $\begin{array}{c}\mathrm{k}^{\prime} \\
\left(\mathrm{mm}^{-1}\right)\end{array}$ \\
\hline A & 0.78 \\
M & 0.53 \\
S & 0.35 \\
D & 0.67 \\
\hline
\end{tabular}

Table 4

Vertical distribution of motile pennate diatoms at Station D, 12 Aug. 1964. Barnstable Harbor

\begin{tabular}{|cc|}
\hline $\begin{array}{c}\text { Depth Interval } \\
(\mathrm{mm})\end{array}$ & $\begin{array}{c}\text { Cells under } \mathrm{cm}^{2} \text { in } \\
\text { each depth interval }\end{array}$ \\
\hline $0-1$ & 10400 \\
$1-2$ & 10400 \\
$2-3$ & 8300 \\
$3-4$ & 3100 \\
$4-5$ & 2080 \\
$5-6$ & 2600 \\
$6-7$ & 1600 \\
$7-8$ & 1600 \\
$8-9$ & 1600 \\
$9-10$ & 1040 \\
$10-15$ & 4200 \\
$15-20$ & 2300 \\
$20-25$ & 2700 \\
$25-30$ & 1900 \\
$30-40$ & ca. 530 \\
$40-50$ & ca. 10 \\
\hline
\end{tabular}

The vertical distribution pattern of the pennate diatom population at Station $D$ is given in Table 4. Over 42,000 living cells were found in the first $\mathrm{cm}, 6,500$ in the second $\mathrm{cm}$, and 4,600 in the third cm. Motile cells were found as deep as $5 \mathrm{~cm}$ but the limitations of the method prevent quantitative significance from being attached when less than 1000 cells $\mathrm{cm}^{-3}$ are reported. These results merely indicate that living cells were detected at those depths and that there were more in the $4 \mathrm{~cm}$ fraction than the $5 \mathrm{~cm}$ fraction. The diatom population at Station $\mathrm{D}$ is very patchy and in other cores an order of magnitude in greater number of cells in the upper few $\mathrm{mm}$ was sometimes 
seen. The predominate organism in the upper few $\mathrm{mm}$ was Hantzschia amphioxys, var. major Grun. Several Navicula sp. and Nitzschia sp. were present.

\section{DISCUSSION}

The vertical distribution patterns of the pigments showed similarities that were common to all stations. The concentrations of the chlorophylls and the fucoxanthins were greatest in the first few millimeters and decreased at approximately a steady rate with depth. However, the concentrations of these pigments at $5 \mathrm{~cm}$ were higher than expected. Carotene, diadinoxanthin and diatoxanthin concentrations did not decrease with depth but tended to be constant, or, in one case, to increase.

There were quantitative differences in the pigment distributions which can be attributed to the different types of environments. Stations $A$ and $M$ are subjected to weak tidal currents as is evidenced by the poor sorting of the sediments. At both of these stations only the top few millimeters of the sediment are aerobic. Turnover of the sediments is predominately the result of the biological activity of the large invertebrate populations and is relatively slow. In such an environment, the chlorophyll and fucoxanthin concentrations are extremely high in the frrst millimeter and decline rapidly with increasing depth. The other xanthophylls and carotene concentrations were essentially constant with depth. At the two sand flat stations, S and D, the sediments are aerobic to a few centimeters (SANDrRs et al. 1962). Both areas are swept by stronger tidal currents and, although some turnover of the upper layer of the sediments is the result of biological activity, the predominate factor must be tidal action. Under these conditions, the highest pigment concentrations were found just below the sediment surface and the absolute and relative decline in chlorophyll and fucoxanthin concentration was less than at Stations $A$ and $M$.

The distribution of photosynthetic organisms at these four stations has only been partially studied. No quantitative data exists for Stations $A, M$ and $S$ and only the motile pennate diatoms have been investigated at Station D. In addition to these diatoms, there are large populations of blue-green algae and sessile chrysophyceae present as well as smaller populations of non-motile diatoms. These, however, seem to be limited to the upper $3 \mathrm{~mm}$. Confirming Moul \& Mason (1957), living diatoms were detected as deep as $5 \mathrm{~cm}$ but the numbers present could not have accounted for the high concentrations of pigments found. Furthermore, a few diatom frustules were found at these depths.

The rate of decomposition of photosynthetic pigments in an organic-rich anaerobic environment is unknown but it is usually assumed to be relatively rapid (SANDERS et al. 1962). If such is the case, one would conclude that the chlorophyll at 4 or $5 \mathrm{~cm}$ could not have been released from the cellular environment for very long. Of the immediate decomposition products of chlorophyll, only phaeophytin-a could be quantitatively determined. Other products such as chlorophyllides and phaeophorbides were extracted from the sediments but did not move from the origin of the paper chromatograph. A qualitative inspection of the chromatograph showed, in general, more degradation products at Stations $A$ and $M$ than at Stations $S$ and D, but in all 
cases they appeared to be a minor constituent of the pigment mixture. The fact that carotene concentrations did not decrease with depth may be a reflection of its greater stability under the existing conditions.

Table 5

Per cent of organic carbon as total pigments in intertidal sediments. Barnstable Harbor

\begin{tabular}{|ccccc|}
\hline $\begin{array}{c}\text { Depth } \\
\text { Interval }\end{array}$ & $\mathrm{A}$ & $\mathrm{M}$ & Station & $\mathrm{S}$ \\
\hline $1 \mathrm{~mm}$ & 1.40 & .85 & 1.37 & $\mathrm{D}$ \\
$1.1 \mathrm{~cm}$ & .53 & .35 & .59 & .70 \\
$2.1 \mathrm{~cm}$ & .22 & .58 & 1.32 & 1.23 \\
$3.1 \mathrm{~cm}$ & .31 & .49 & 1.02 & .68 \\
$4.1 \mathrm{~cm}$ & .41 & .59 & 1.37 & .66 \\
$5.1 \mathrm{~cm}$ & .34 & .27 & 1.16 & .65 \\
\hline
\end{tabular}

No obvious correlation between the per cent organic content and the concentration of chlorophyll-a was found. However, the per cent of organic carbon occurring as total plant pigments (Table 5) can be correlated with some of the physical environmental factors. At Stations A and M, where only the surface $\mathrm{mm}$ is aerobic, the per cent of organic material as pigments is very high in the surface mm and drops to a low relatively constant value below this level. At Station $\mathrm{D}$, where the benthic diatoms are concentrated in the upper $\mathrm{cm}$ (Table 4) and the mixing from tidal currents is greater, a high value is found in the upper $\mathrm{cm}$. Values below this depth are nearly constant and considerably higher than those found in the lower sections at Stations A and M. At Station $S$, the most aerobic of the stations and at which the sediments are most actively turned over by tidal currents, the values are high and nearly constant over the entire length of the $5 \mathrm{~cm}$ core. The per cent of organic material occurring as pigments also may indicate the location of the highest concentrations of pigment containing organisms within the core.

Limitations of the method of measuring the penetration of solar radiation through the upper few $\mathrm{mm}$ of the sediments have previously been discussed (TAYLOR 1964). The attenuation coefficients are not precise but they do give a rough idea of the light available at different depths in the sediments at the four stations. As pointed out by Prof. D. J. CRISP (personal communication), the values of the coefficients are based on the logarithm to the base 10 rather than as defined by TAYLOR (1964). Since it is common practice to use this system in describing light attenuation through sea water (SVERDRUp et al. 1942, p. 82), it is proposed to continue such designation for sediments rather than the use of natural logarithms.

The depth to which one per cent of the incident solar radiation penetrates was about $2 \mathrm{~mm}$ at Station $A, 3 \mathrm{~mm}$ at Station $\mathrm{D}, 3.5 \mathrm{~mm}$ at Station $\mathrm{M}$ and a little over $5 \mathrm{~mm}$ at Station $S$. In general, these values agree with the depths at which the highest pigment concentrations were found but it is obvious from both the pigment analyses and the little cell count data available that many photosynthetic cells exist at depths at which the light level is too low for photosynthesis. The possibility of heterotrophic growth is intriguing, but a clarification of the source of the large concentrations of 
pigments coupled with the low concentrations of pigment degradation products in these sediments must await further investigation.

\section{SUMMARY}

1. Chromatographic analyses were used to determine the concentration of plant pigments in the sediments at four intertidal stations at Barnstable Harbor, Massachusetts, U.S.A. Two of the stations were sand flats exposed to relatively strong tidal currents and two were mud flats subject to weak currents. In general, highest concentrations of all pigments were found in the upper $\mathrm{mm}$. Chlorophyll-a, chlorophyll-c and fucoxanthin concentrations decreased with depth but considerable quantities (20 to $50 \%$ of surface values) were found at $5 \mathrm{~cm}$. Diatoxanthin, diadinoxanthin and carotene concentrations did not decrease with depth. Quantitative differences between the stations were noted.

2. With one exception, measurements of light attenuation through these sediments, were roughly correlated with mean particle size.

3. On one station, living diatoms were found as deep as $5 \mathrm{~cm}$, but the vertical distribution of the pigments could not be explained by the diatom distribution.

\section{LITER ATURE CITED}

AyERs, J. C., 1959. The hydrology of Barnstable Harbor, Massachusetts. Limnol. Oceanogr. 4, $448-462$.

JrFfrey, S. W., 1961. Paper-chromatographic separation of chlorophylls and carotenoids from marine algae. Biochem. J. 80, 336-342.

KAR, B. K., 1937. Uber das Verhalten der Plastidenfarbstoffe photoperiodisch reagierender Planzen bei verschiodenem Lichtgenuß. Planta 26, 420-462

Karrer, P. \& Wurgler, E., 1943. Absorptionsspektren ciniger Carotinoids. Helv. dhim. Acta $26,117-121$.

Moul, E. T. MAson, D., 1957. Study of diatom populations on sand and mud flats in the Woods Hole area. Biol. Bull. mar. biol. Lab., Woods Hole 113, 351.

PatTerson, J. \& Parsons, T. L., 1963. Distribution of chlorophyll-a and degradation products in various marine materials. Limnol. Oceanogr. 8, 355-356.

Sanders, H. L., Goudsmit, E. M., Mulds, E. L. \& Hampson, G. E., 1962. A study of the intertidal fauna of Barnstable Harbor, Massachusetts. Limnol. Oceanogr. 7, 63-79.

Smith, J. H. C. \& Benitez, A., 1955. Chlorophylls: analysis in plant matcrials. In: Modern methods of plant analysis. Ed. by K. Paech \& M. Y. Tracey. Springer, Berlin, 4, 142-196.

Sverdmup, H. U., Johnson, M. W. \&. Flfmung, R. H., 1942. The oceans; their physics, chemistry and general biology. Prentice Hall, Englewood Clifs, N. J., 1087 pp.

TAYLOR, W. R., 1964. Light and photosynthesis in intertidal benthic diatoms. Helgolander wiss, Meeresunters, 10, 29-37.

- \& Geblanin, C. D., 1964. Chromatographic analyses of plant pigments in intertidal sediments. Biol. Bull. mar. biol. Lab., Woods Hole 127, 393.

ZSCheILE, F. P. \& COMAR, C. L., 1941. Influence of preparative procedure on the parity of chlorophyll components as shown by absorption spectra. Bot. Gaz. 102, 463-481. 